https://doi.org/10.18485/dpls_pld.2020.6.ch1

811.112.2'42

Johannes Dahm

Université de Nantes

\title{
"SERBIA AND THE EU": \\ DISCURSIVE FRAMING AND IMPRINTING EFFECTS ON RECURRENT SPEECH PATTERNS USED IN THE GERMAN-LANGUAGE PRESS
}

\begin{abstract}
This contribution marks the starting point of a more wide-ranging study that covers German-language news discourse concerning the possible future enlargement of the European Union with regard to the Western Balkan countries (2025). In order to approach the topic, this paper brings into focus a corpus linguistic perspective. It analyses the surface of the current German-language press discourse concerning the accession of Serbia to the European Union against the background of selected press articles $(2018,2017)$ related to this particular issue. Discursive framing and imprinting effects on recurrent speech patterns will be uncovered using Sketch Engine - a text analysis software.
\end{abstract}

Key words: Discourse studies, Corpus linguistics, German-language press, Serbia, European Union, Framing

\section{Introduction}

Croatia was the last state to join the European Union in July 2013. Slovenia, another former Yugoslav Republic with which Serbia experienced the so-called "actually existing socialism", became member of the EU in may 2004. Romania and Bulgaria, two immediate neighbours on Serbia's eastern border, joined the EU in 2007. Today, the political map of Europe shows a gap within the Balkan Peninsula; a gap, which including Serbia - represents the so-called Western Balkan countries that do not (yet) belong to the EU: Albania, Bosnia and Herzegovina, Kosovo, Macedonia, Montenegro. 
Serbia applied for European Union membership in December 2009, in march 2012 the state officially became a candidate country. Since the beginning of 2018 - certainly there have been reports and discussions for years -, the accession of Serbia to the European Union has become a prominent theme amongst German-language newspapers: 2025 seems now to be the possible date for Serbia (and Montenegro) to integrate with the EU.

Certainly, to some extend somehow hegemonic-appearing German news discourse concerning the Enlargement of the European Union (2025) foregrounds Central-European interests and rather ignores concerns of the affected states in Southeast Europe. Political, historical, economic or cultural challenges are often presented against the background of the entire Western-Balkan region. In the first instance, it seems that unsolved conflicts are the main reason why the EU still hesitates with regard to its integration, notwithstanding that - in the meantime - aspirations and interests have changed on the part of some of the concerned states.

From a Central-European point of view, the perceptions of the Balkans and Serbia - where the unsolved conflicts between the successor states of Yugoslavia seem to be the most distinct according to news reports - remain biased; they seem to be dominated by recurrent patterns: Serbia is depicted as a threshold country, not only from an industrial point of view but also culturally and politically: geographically situated in Europe - at the same time still on its way to Europe (cf. Becker/Engelberg 2008: 9).

Especially the Yugoslav Wars, but also reports about obscure pyramid schemes, violence in Albania, food riots in Bulgaria, activities of the 'Balkan-Mafia' and the political trends in Rumania after the execution of Ceaussescu seem to confirm the thesis of a 'barbarous' region in Europe. Media coverage strengthened stereotypes that have also been projected on Serbia during the Milošević era (cf. Becker/Engelberg 2008: 12). Maria Todorova (1997: 3) was one of the first researchers to retrace the evolution of the (historical) discourse that forged representations about the region - using "the specter of the Balkans" as an analytical category. "Balkanization" as a Schimpfwort (or: disparagement) - "more persistent over time than others" (Todorova 1997: 3) - turned out "to denote the parcelization of large and viable political units but also had become a synonym for a reversion to the tribal, the backward, the primitive, the barbarian" (Todorova 1997: 3). According to Todorova (1997: 18), 
"balkanism was formed gradually in the course of two centuries and crystallized in a specific discourse [discursive hardening] around the Balkan wars and World War I. In the next decades, it gained some additional features but these accretions were mostly a matter of detail, not of essence". Since today the "balkanist discourse [...] is present primarily in journalistic and quasi-journalistic literary forms [...]" (Todorova 1997: 19), one has to consider its impact on the present news coverage. If one assumes that a(n) (overlaying and influential) "balkanist discourse" exists (and circulates within the media), a certain type of a Yugoslav discourse as well as some kind of a Serbian discourse - which provide discursive strands and analytical categories as well - should be considered, too. Time and again there are more or less influential intellectuals like, for example, Noam Chomsky (cf. Džalto 2018) or - with regard to the German speaking countries - Peter Handke (cf. 1996), who comment on the situation in Serbia; comments that often mirror positions that sometimes lead to discussions that also keep the (current) media discourse alive.

Selective and isolated research studies about news framing of Serbia and its effects do exist (cf. for instance: Kapranov 2016 ; Lecheler/De Vreese, Claes H. 2010). However, this paper wants to mark a starting point of a more wide-ranging study that tries to bring into focus Germanlanguage news discourse concerning the (possible) future enlargement of the European Union with regard to the Western Balkan countries (2025). In order to approach the topic, this paper brings into focus a corpus linguistic research perspective. It analyses the surface of the current German-language press discourse concerning the accession of Serbia to the European Union against the background of press articles $(2018,2017)$. The main aim of the more wide-ranging study, however, is to uncover representations and underlying social knowledge structures that shape the language use as it manifests itself within the particular discourse. In order to explore these socio-cognitive dimensions (social cognition), further research has to be done.

This paper shortly presents the theoretical and methodological framework. Thereafter, the corpus and its composition as well as the different phases of the corpus analysis - the latter ones can merely be exemplified - will be at the centre of attention. The last section discusses further perspectives. 


\section{Theoretical and methodological framework}

In order to get insights into socio-cognitive structures and processes which come to pass within the (rhizomatic) discursive universe - where different actors encounter and discursive practices shape reality (cf. Foucault 1973)-, the interdisciplinary framework called upon in this study interrelates theories and concepts that belong (today) to different scientific fields and that coincide with each other at the crossroads of language and society in the discipline of discourse studies: Social Representation Theory and Frame semantics. Social cognition is approached considering two perspectives on the notion of knowledge (cf. Fraas 2005): The first one is socio-scientific; and the socio psychological 'Social Representation Theory' (cf. Moscovici 1961) makes allowance for this field: besides cognitive dimensions of knowledge structures (which are not denied), social and societal factors play an important part when it comes to the processes of 'objectivation' and 'anchoring' of social representations within a society (cf. Jodelet 2003 ; Abric 2003) - and within a given discourse. The second notion of knowledge originates from cognitive science and has applications in the field of cognitive linguistics, hence, in cognitive semantics, a cognitively and psychologically oriented approach to semantics (cf. Langacker 1988; Fillmore 1982). The fundamental principles of cognitive linguistics - as seen, at least, by linguists working in the field of Frame-Semantics (cf. Ziem 2008) - are based on holistic language models which are cognitively and psychologically informed and which distance themselves from the dictum of an innate grammar (cf. Chomsky 1980): Language (and knowledge) is to the core 'social' and it is subject to the influence of the social environment; both, experiential knowledge and world knowledge come into play using language.

The theoretical and methodological framework called upon in this study - which due to space restrictions cannot be exposed here - is based on a previous research which focused the theoretical and methodological interoperability between semantic frames and social representations against the background of a linguistic discourse analysis (cf. Dahm 2018). The respective concepts (semantic frames / social representations) are (i. a.) based on the psychological principles of salience (cf. Giora 2003) and frequency ('frequency effects') (cf. Behrens/Pfäder 2016). In the scope of usage-based approaches to language, frequency effects are not only called up in order to justify the analysis of language corpora; they 
provide - in fact - a basis that allows the analyst to reconstruct networks (form-networks, semantic-networks) out of language corpora and to deduce 'constructions' from prototypical categories (cf. Lasch 2016: 18). Observed salience and frequency effects serve the analyst to describe the degree of mental accessibility to notional knowledge - under certain (context related) conditions. At that point, the potential of text analysis software (in the framework of corpus linguistic approaches for discourse analysis, that focus on socio-cognitive constructs) becomes clear. The basic idea behind the interdisciplinary theory is that lexical expressions operate as 'frame evoking elements' (FEEs) (cf. Baker 2009) ; they have the potential to provide a (cognitive) framework and thereby mobilize background knowledge - that might by necessary for understanding: In this regard "[...] it is frequently possible to show that the same 'facts' can be presented within different framings, framings, which make them out as different 'facts' (Fillmore 1982: 125).

From a very practical and decidedly corpus linguistic point of view, the notion of discourse refers here to virtual text corpora - dimensions which analysts (working empirically) cannot catch up entirely - which are governed (in the broadest sense) by semantic criteria (cf. Busse/Teubert 2013: 16). A corpus (as a representative excerpt) can only consist of a selection of texts which participate in an intertextual network 'belonging' to a certain discourse. It becomes clear that within the scope of a (corpus linguistic) discourse analysis, it is in the first instance the corpus itself which constitutes the object of investigation (cf. Busse/Teubert 2013).

\section{Analysis}

59 texts constitute the corpus - in large parts online newspaper articles, very few originate from other electronic media (broadcasting services: DW, MDR, SRF). These texts have been published in 2018, mostly by German online newspapers ( 3 articles have been published in 2017) - with the exception of those published by the NZZ (Switzerland) and by Kosmo (Austria):

Neue Zürcher Zeitung - 14 articles ; Frankfurter Allgemeine Zeitung - 12 articles ; Deutsche Welle 8 - articles ; Süddeutsche Zeitung - 6 articles ; Die Zeit - 6 articles ; Die Welt - 5 articles ; Spiegel Online - 2 articles ; Focus - 1 article ; Kosmo - 1 article ; Mitteldeutscher Rundfunk - 1 article ; Schweizer Radio und Fernsehen - 1 article ; Der Tagesspiegel - 1 article ; Die Welt - 1 article. 
The corpus has to be aggrandized in order to achieve representativeness; the balance with regard to the number of articles published in different newspapers has to be reconsidered; the (general) number of cited newspapers, as well, has to be rethought; the political spectrum and the newspapers' political orientation has to be kept in mind, too. Eventually, different approaches may be aimed at: synchronic or diachronic approaches, for instance.

The 59 articles have been chosen with regard to their topicality and their up-to-dateness. By means of keywords like 'Serbien' or 'Europäische Union', the texts have been identified and added to the corpus. The software Sketch Engine (cf. Kilgarriff et al. 2014; Rychlý 2008) compiles the corpus $(38,419$ words in this specific case) so that the latter can then be searched by the analyst. In order to get insights into the discourse, keywords will initially be identified. Keywords structure the discourse, they are (highly) frequent, they bind semantically charged collocation partners (words, that might operate as structuring elements themselves), they dominantly evoke - as FEEs - semantic frames and act as central or peripheral elements of social representations. The existence of dominant collocations within which keywords are involved, might indicate insights into the structure of a social representation (core/periphery); thereby, networks of semantic frames might be analyzed (cf. Dahm 2018).

Eventually, the following analysis - which merely develops and establishes an exemplary access to the discourse/the corpus at the surface -, follows a certain procedure with regard to the sequential arrangement: frequencies (a); collocations (b); word sketches (c); sketch difference (d) - the linguistic frame analysis (e) / predication analysis (cf. Ziem 2008) has not been completed yet. Ideally, every phase of this sequential arrangement has to be amplified in order to exploit the maximum potential of the interdisciplinary approach. Consequently, the greatest possible number of keywords has to be identified; the collocation analysis could be conducted with regard to 'collocational networks' (cf. Williams 1998); the greatest possible number of word sketches and sketch differences should be considered. The frame analysis should then focus upon a large number of frame evoking elements. Given these circumstances, the discursive architecture - and its underlying rhizomatic structure (semantic frames/ social representations appearing as networks) - could be rigorously uncovered (cf. Dahm 2018). 
Frequencies (a)

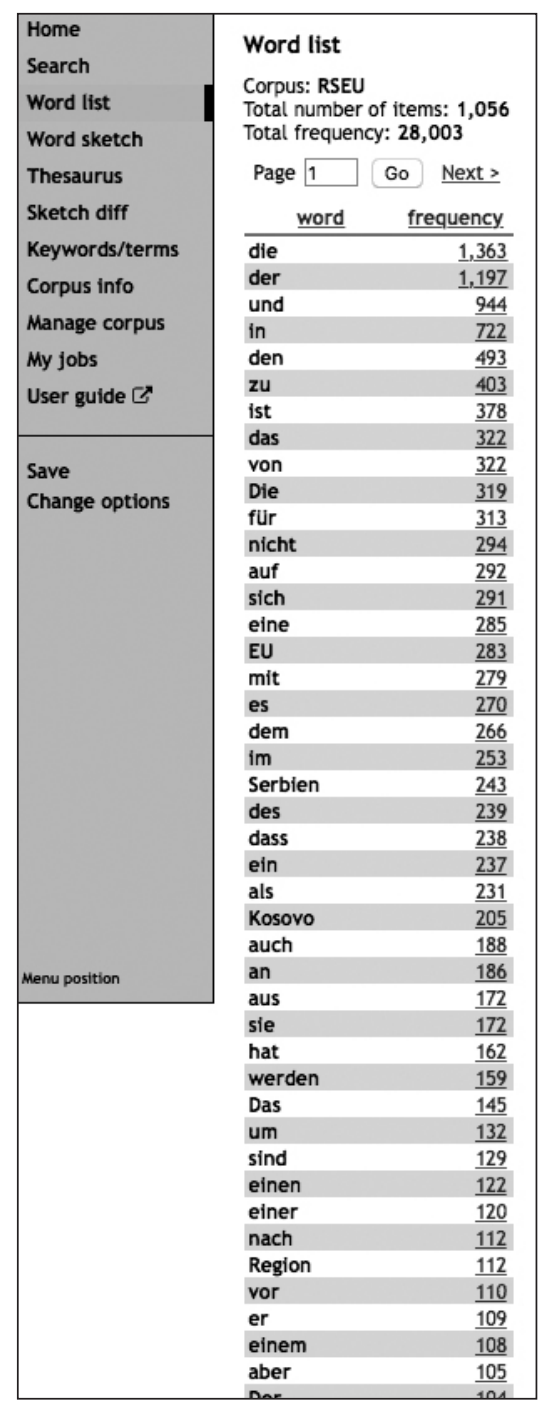

Figure 1. Word list

Figure 1 shows an excerpt of the word list. The most frequently occurring words are depicted regardless of whether these words are content words (nouns, lexical verbs and adjectives, for instance) or function words - also called grammatical words (prepositions, pronouns, auxiliary verbs, conjunctions, grammatical articles or particles, for instance). Within the 
scope of this exploratory research, the focus is firstly laid on (semantically loaded) content words (frequency effects, salience effects) - excursus with regard to grammatical constructions, however, will be considered, too.

\begin{tabular}{|c|l|c|}
\hline Position & Content word & Frequency \\
\hline 1 & EU & 283 \\
\hline 2 & Serbien & 243 \\
\hline 3 & Kosovo & 205 \\
\hline 4 & Region & 112 \\
\hline 5 & Balkan & 99 \\
\hline 6 & Montenegro & 88 \\
\hline 7 & zwischen & 87 \\
\hline 8 & Länder & 77 \\
\hline 9 & Union & 75 \\
\hline 10 & Staaten & 73 \\
\hline 11 & Vučić & 71 \\
\hline 12 & Brüssel & 69 \\
\hline 13 & Belgrad & 67 \\
\hline 14 & Westbalkan & 66 \\
\hline 15 & Mazedonien & 64 \\
\hline
\end{tabular}

Table 1. Word frequencies (mostly content words)

Table 1 shows the 15 most frequently occurring content words within the analyzed corpus; EU, Serbien, Kosovo, Region and Balkan, for instance, will be considered as belonging to the most dominant keywords (of course there are others, too). Function words have - in the course of this manual classification - (mostly) been excluded in order to get an overview of those words that name objects of reality as well as their qualities.

The word zwischen (between), however - to dare a short excursus -, has been considered here, since words that collocate with this preposition (as with others, too) might reveal interesting insights into the discourse. One could ask, for instance: What could probably occur/stand/exist... between two entities A and B? - to put it quite imprecise at this stage.

Figure 2 shows a concordance excerpt of zwischen; what attracts attention forthright is that the paradigmatic elements Serbien (Serbia) / Belgrad (Belgrade) / Vučić - on the one hand - and Kosovo (Kosovo) / Prishtina / (Pristina) / Thaçi - on the other hand - represent at least two differentkinds ofentities (poles orreferences) which are apparently involved 


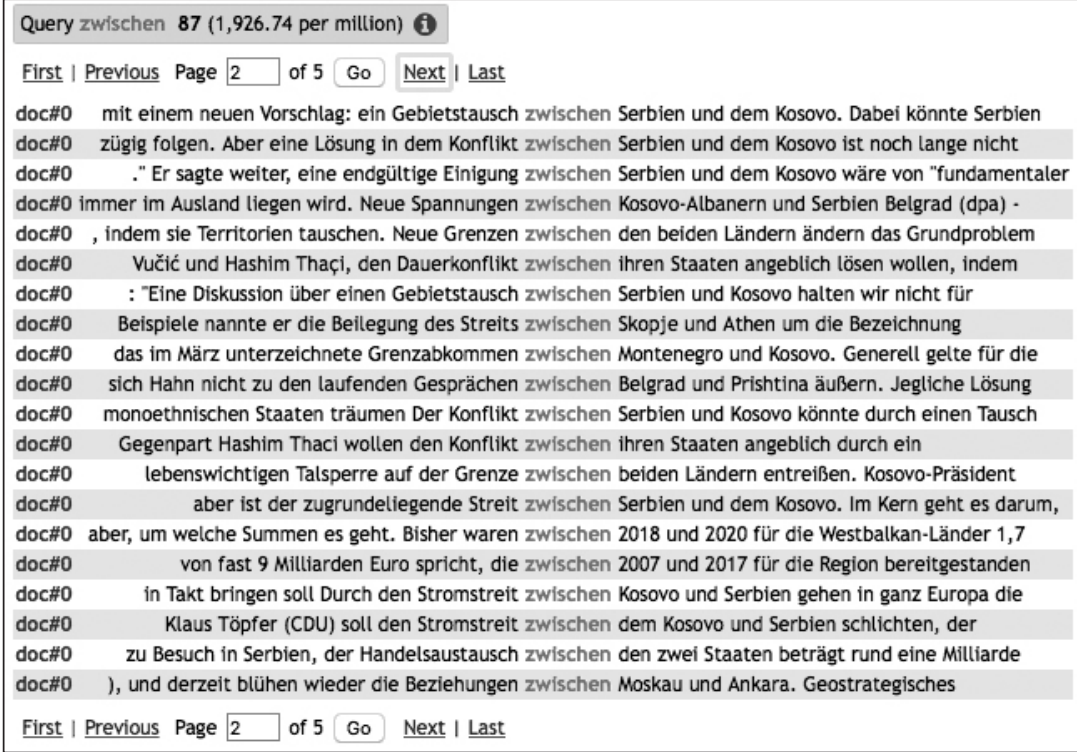

Figure 2. Concordance / KWIC (key word in context): zwischen

here. What are they involved in? Konflikt (conflict), Gebietsaustausch (devision of territory), Einigung (agreement), Spannungen (tensions), Grenzen (borders), Gespräch (dialogue), Streit (dispute), Stromstreit (electricity dispute) ... This short concordance excerpt, by itself, reveals a seemingly prominent strand and a recurring motif which manifests itself within the analyzed discourse. Now, there is a strong temptation to pursue this line in order to document this pattern statistically and to identify other pairs of opposites - their interspaces - and paradigmatic relations: Moskau (Moscow) / Ankara ; Skopje / Athen (Athens) ; Montenegro / Kosovo...

The most frequently occurring words will now have to be analyzed with regard to their (semantic) binding strength and their binding affinities. Frequently occurring (content) words which also possess cohesive force (can) meet the criteria for discourse structuring key words. Within the scope of this paper, two keywords have been identified (of course, there are others, too): Europa, Serbien.

\section{Collocations (b)}

Sketch Engine offers a certain number of association scores (cf. Evert 2005) and parameters (range, minimum frequencies) which can be selected in order to identify collocations and recurrent patterns within a 
given corpus: T-score, Mutual-Information, log-likelihood, logDice... The logDice-score lends itself to the analysis of small corpora (cf. Rychlý 2008).

\section{Collocation candidates 8}

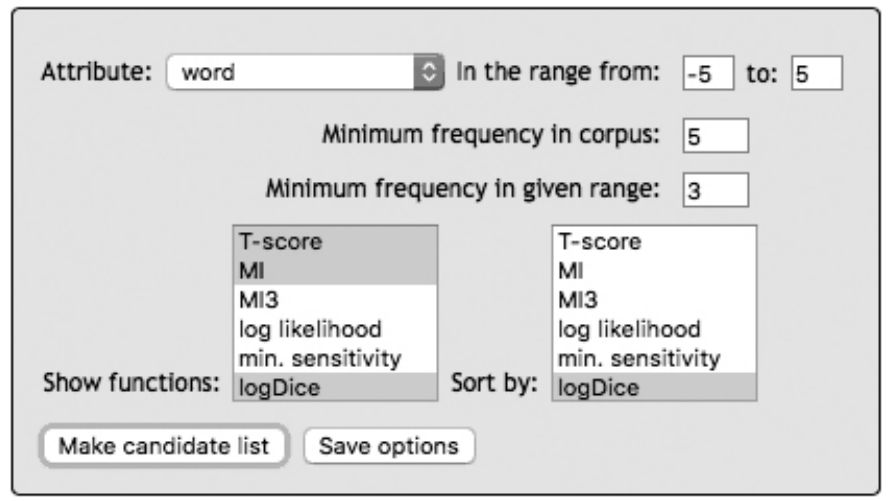

Figure 3. Collocation candidates

Collocation-candidate lists have been made - using the logDicescore and respecting the adjustments concerning further parameters shown in Figure 3 - for the two selected keywords.

\begin{tabular}{|c|c|c|c|c|c|}
\hline & $\frac{\text { Cooccurrence }}{\text { count }}$ & $\frac{\text { Candidate }}{\text { count }}$ & $\underline{T \text {-score }}$ & MI & $\underline{\text { logDice }}$ \\
\hline$\underline{P} \mid \underline{N}$ Balkan & 8 & 99 & 2.778 & 5.810 & 10.642 \\
\hline$\underline{P} \mid \underline{N}$ ganz & 4 & 22 & 1.984 & 6.980 & 10.557 \\
\hline$\underline{P} \mid \underline{N}$ nach & 8 & 112 & 2.771 & 5.632 & 10.532 \\
\hline $\mathrm{P} \mid \mathrm{N}$ man & 6 & 70 & 2.408 & 5.895 & 10.508 \\
\hline $\bar{P} \mid \bar{N}$ Teil & 4 & 28 & 1.979 & 6.632 & 10.460 \\
\hline$\underline{P} \mid \underline{N}$ geworden & 3 & 9 & 1.724 & 7.855 & 10.375 \\
\hline$\underline{P} \mid \underline{N}$ Und & 4 & 46 & 1.966 & 5.916 & 10.205 \\
\hline P | N Aber & 4 & 52 & 1.962 & 5.739 & 10.129 \\
\hline$\underline{P} \mid \underline{N}$ damit & 3 & 29 & 1.707 & 6.167 & 10.030 \\
\hline$\underline{\underline{P}} \mid \underline{\underline{N}}$ am & 4 & 64 & 1.953 & 5.440 & 9.988 \\
\hline$\underline{p} \mid \underline{N}$ Länder & 4 & 77 & 1.944 & 5.173 & 9.850 \\
\hline
\end{tabular}

Figure 4. Collocations - Europa

Figure 4 shows an excerpt of the collocation-candidate list concerning the keyword Europa. Further collocation-candidates, which are not depicted here are function words. The preposition nach (to, towards), for instance, shows the same number of cooccurrences (8), in conjunction with Europa, as the content word Balkan. However, the logDice-score 
is more important in the case of Balkan - binding affinities are stronger. Moreover, nach has a higher 'candidate-count' (122) than Balkan (99); the preposition does (preferably) cooccur with other candidates (or with a certain number of other candidates). It is striking, that - within the specific corpus - Europa does not preferably cooccur with Serbien but with Balkan. Further research could be done following this line in order to reinforce possible hypothesis; for instance: Serbia - within this specific EU-discourse - is inseparably connected to the Balkan region; Serbia is seen against this specific background...

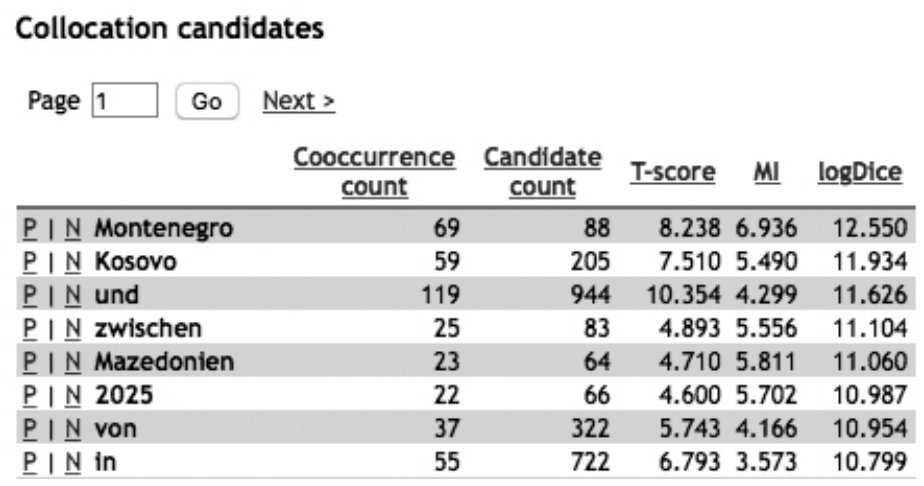

Figure 5. Collocations - Serbien

Figure 5 shows the collocation candidates that preferably cooccur with Serbien. Within this particular discourse, Serbia and Montenegro different from Albania or Bosnia-Herzegovina, for example - appear as the 'frontrunners' when it comes to the chances concerning the accession to the European Union; they are frequently mentioned together within this context. It would be interesting to analyze the characteristics of this collocation, and - on the other hand - to analyze what kind of patterns are typical for the single occurrences, where the respective words occur without the name of the respective neighboring country. Sketch Engine, on this particular aspect, differentiates between positive and negative concordances which make it possible to access directly to these particular segments within the corpus.

The logDice-score for Montenegro is stronger than the score for Kosovo, even though, the candidate-count of the latter is higher. When Montenegro occurs within the discourse, it preferably occurs together with Serbien. Kosovo, however, is used in a range of certain other contexts (Albania, for example). 


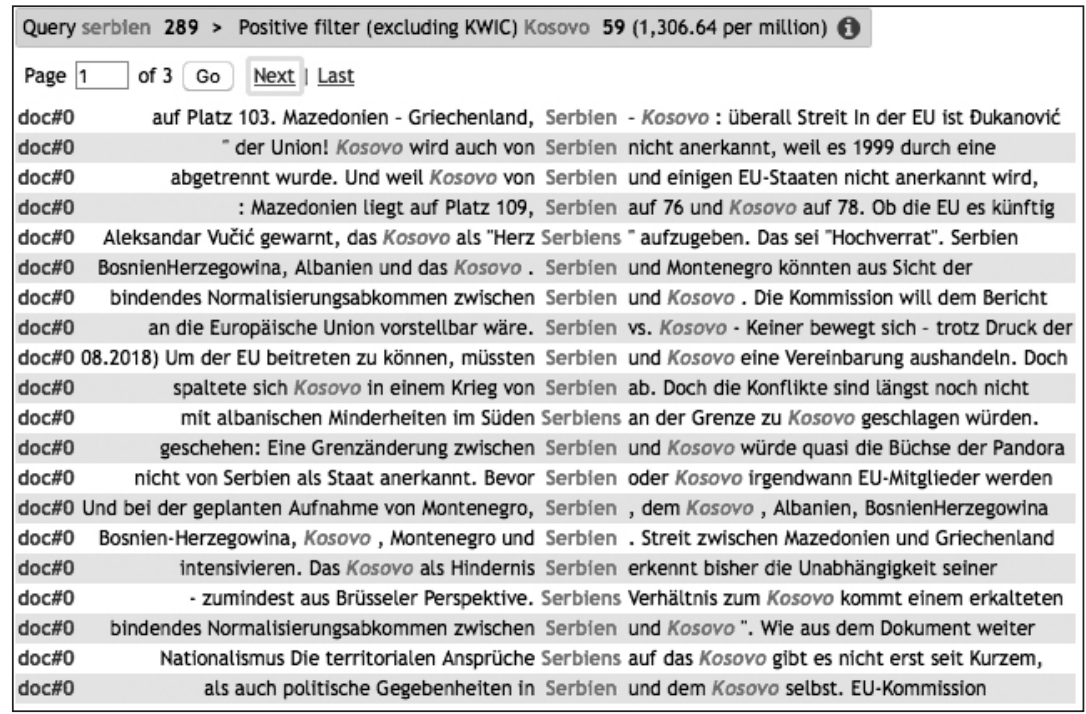

Figure 7. Concordance / KWIC: Serbien \& Kosovo

Word Sketches (c)

More insights into the discursive architecture can be guaranteed using word sketches which provide a summary of a word's behavior. A word sketch is defined on the software's homepage as "a one-page summary of the word's grammatical and collocational behaviour. It shows the word's collocates categorized by grammatical relations such as words that serve as an object of the verb, words that serve as a subject of the verb, words that modify the word etc." (www.sketchengine.eu).

Figure 8 shows a word sketch based on the lemma Serbien. In terms of constructions, Serbien occurs 289 times as a name, 99 times in nominative, 90 times in dative, 54 times in accusative and 46 times in genitive constructions. The analysis of the use of Serbien within the scope of genitive constructions, for instance, offers interesting insights into discursive framing processes since it reveals (i.a.) 'possessions', 'belongings' or 'motivations' attributed to Serbien. 
serbien ${ }_{\text {RSEU freq }}^{\text {(noun) }} \underline{289}(6,400.31$ per million)

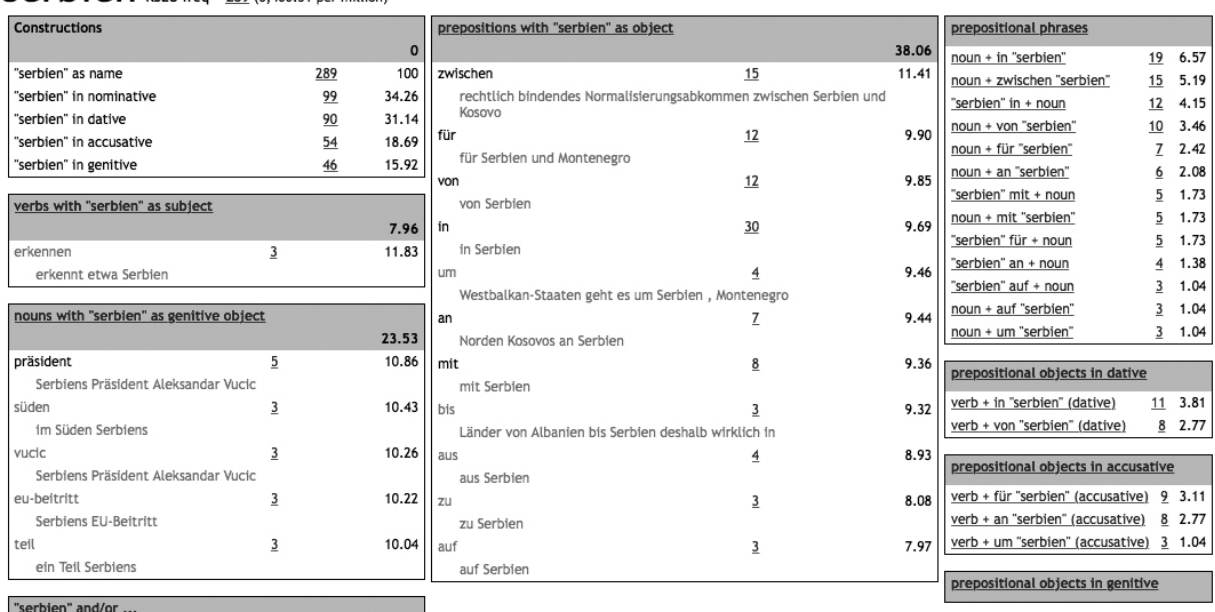

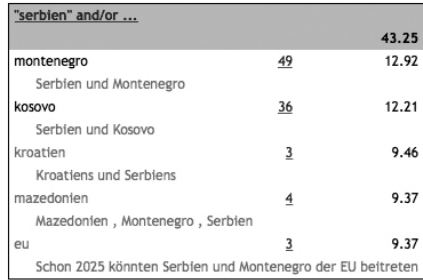

Figure 8. Word sketch - Serbien

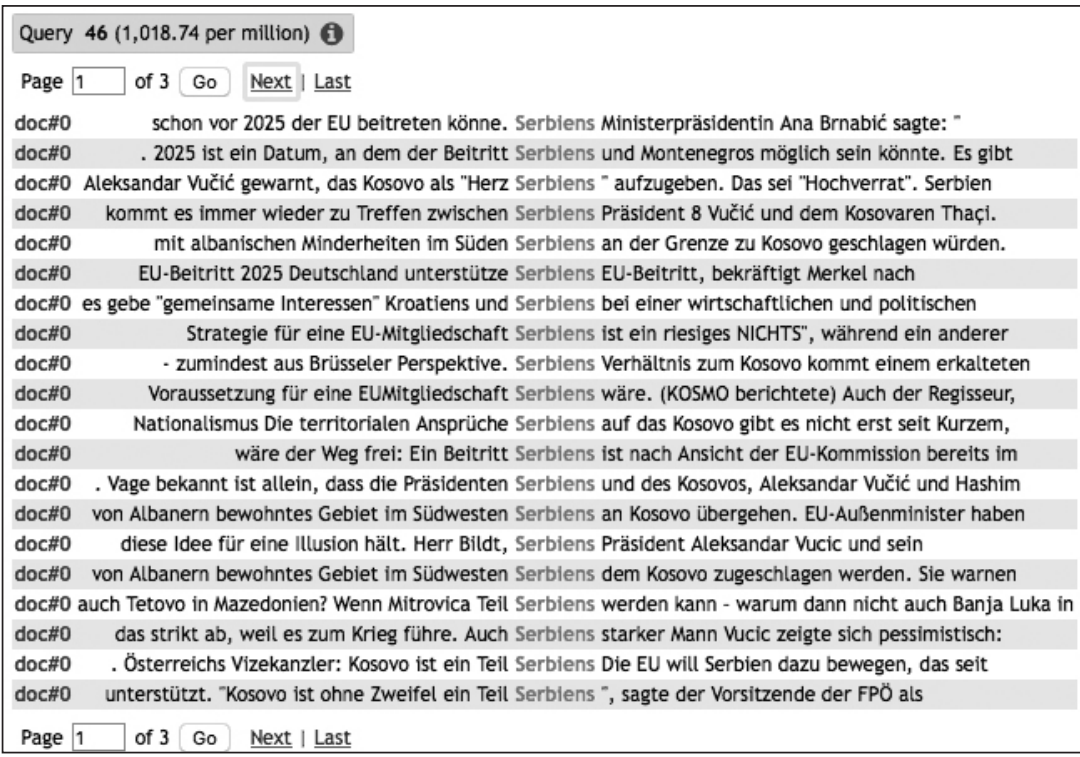

Figure 9. - Serbien in genitive 
Figure 9 shows an excerpt of the concordance list concerning SerbienS (genitive constructions). There is a certain number of possessions or properties attributed to Serbia: Kosovo as the heart of ; Albanian minorities in the south of ; Kosovo as a part of ; Mitrovica as a part of ; inhabited areas in the southwest belonging to ... Moreover, Serbia has: common interests (with Croatia) ; territorial claims ; its own history ; its Silicon Valley ; its police ; politics ; deficits ; aspirations ; ... Serbia has: a prime minister ; a president ; a strong man... In order to analyze the evoked frame (Serbien as FEE), all occurrences have to be identified statistically and classified semantically.

With respect to the preposition in (with Serbien as object) a further dimension can be added to the analysis:

\begin{tabular}{|c|c|c|}
\hline \multicolumn{3}{|c|}{ Query 30 (664.39 per million) $\mathbf{i}$} \\
\hline Page 1 & of 2 Go & Next | Last \\
\hline doc\#0 & \multicolumn{2}{|r|}{ und zurückgehende Pressefreiheit in Serbien und Montenegro. Dort haben sich Regime } \\
\hline doc\#0 & \multicolumn{2}{|c|}{, wenn sie billige Arbeitskräfte anbieten. In Serbien bekommen Industriearbeiter vielleicht } \\
\hline doc\#0 & \multicolumn{2}{|r|}{ sonst? "Als Erfolg könnte Präsident Vučić in Serbien eine nennenswerte Autonomie der serbischen } \\
\hline doc\#0 & \multicolumn{2}{|r|}{ Westbalkan-Strategie vorgestellt, in der Serbien bei zügigen Reformen bis 2025 eine Aufnahme in } \\
\hline doc\#0 & \multicolumn{2}{|c|}{ Aufnahme. Allerdings sind die Hürden etwa in Serbien noch hoch: Das Verhältnis zum Kosovo ist } \\
\hline doc\#0 & \multicolumn{2}{|c|}{ schafft Fakten. Baut Brücken und Stahtwerke in Serbien , Flughäfen in Albanien, Autofabriken in } \\
\hline doc \#0 & \multicolumn{2}{|r|}{ Tag, Vidovdan (St. Veitstag), ein Feiertag in Serbien - ein Gedenken an die Schlacht. Der Einfluss und } \\
\hline doc\#0 & \multicolumn{2}{|r|}{ als auch politische Gegebenheiten in Serbien und dem Kosovo selbst. EU-Kommission } \\
\hline doc\#0 & \multicolumn{2}{|r|}{ hinzu: "Ich glaube, dass die Regierungen in Serbien und Kosovo verantwortungsvoll handeln werden } \\
\hline doc\#0 & \multicolumn{2}{|c|}{ Durchsetzung eines solchen Plans. Vucic hat in Serbien eine starke Stellung und viel Einfluss darauf, } \\
\hline doc \#0 & \multicolumn{2}{|r|}{ gehörten. Er liegt zu einem Viertel in Serbien, ist aber für die Stromund Wasserversorgung } \\
\hline doc\#0 & \multicolumn{2}{|c|}{ Kleinwaffen nirgendwo in Europa so hoch wie in Serbien und Montenegro. Hier kämen auf je 100 Einwohne } \\
\hline doc\#0 & \multicolumn{2}{|r|}{ etabliert. Ähnlich wie Russland, das in Serbien und der Republika Srpska ein Standbein auf dem } \\
\hline doc \#0 & \multicolumn{2}{|r|}{ großen Wirtschaftsdelegation zu Besuch in Serbien, der Handelsaustausch zwischen den zwei } \\
\hline doc \#0 & \multicolumn{2}{|r|}{ Delegation bricht historischen Besuch in Serbien ab Eine kroatische Delegation hat einen als } \\
\hline doc\#0 & \multicolumn{2}{|r|}{ einen als historisch bezeichneten Besuch in Serbien wieder abgebrochen. Der Grund ist, dass der } \\
\hline \multicolumn{3}{|c|}{ doc\#0 . Aber auch auf der anderen Seite der Grenze, in Serbien, hielt die obsessive Fokussierung auf Kosovo } \\
\hline doc\#0 & \multicolumn{2}{|c|}{. Nirgendwo sonst zeigt sich das so stark wie in Serbien. Peking stellt Milliarden für den Bau von } \\
\hline doc\#0 & \multicolumn{2}{|c|}{ Es war der Auftakt der chinesischen Bauwelle in Serbien. Präsident Vucic bezeichnete die Brücke bei } \\
\hline doc\#0 & \multicolumn{2}{|c|}{. 2015 investierten die EU-Mitgliedsländer in Serbien 21,8 Milliarden Euro, China nur 139 Millionen. } \\
\hline Page 1 & of 2 Go & Next I Last \\
\hline
\end{tabular}

Figure 10. Prepositions with Serbien as object: in

Figure 10 shows constructions which use the preposition in (in). One could ask: What happens/exists (or does not) in Serbia - and: what seems to be important (from a German point of view)? Freedom of press ; industrial labour force ; autonomy / self-government ; discussions about strategies ; reforms ; obstacles ; bridges and steel works (financed / built by China) ; a particular festive day ; political importance / actuality ; a 
government ; $1 / 4$ of a barrier lake ; small arms ; a border ; a building boom / construction boom (constructions financed by China) ; foreign direct investment (China) ; riots ; ...

\section{Sketch difference (d)}

"Word sketch difference is used to compare and contrast two words by analysing their collocations and by displaying the collocates divided into categories based on grammatical relations" (www.sketchengine.eu).

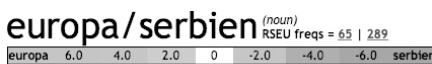
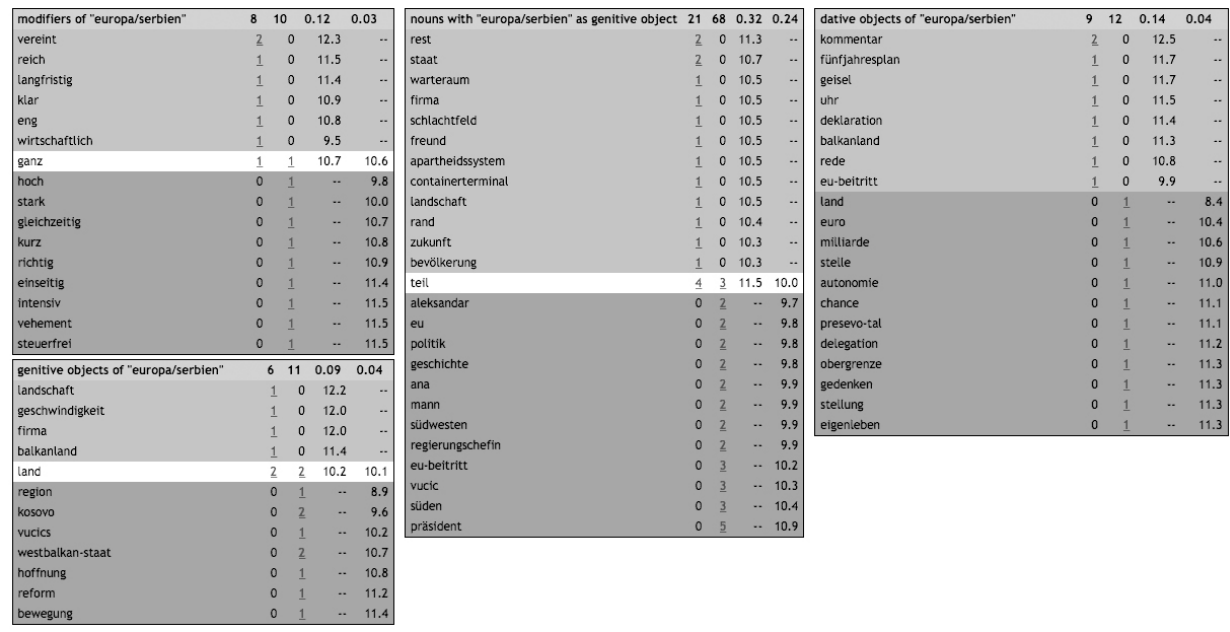

Figure 11. Sketch difference - Europa / Serbien

Figure 11 shows an excerpt of a sketch difference (summary) that has been generated on the basis of the two lemmata Europa and Serbien. Apart from the categories depicted in figure 11 (modifiers of, genitive objects of, nouns with, dative objects of), there are further categories which show respective collocations: verbs with Europa/Serbien as subject; verbs with Europa/Serbien as genitive object; verbs with Europa/Serbien as dative objects; verbs with Europa/Serbien as accusative object, for instance.

As to the 'genitive objects of Europa/Serbien', for instance, one can observe, that within the specific discourse, it is - on the one hand - about Europe's landscapes and Europe's pace or speed; whereas on the other hand, it is about Serbia's hope and Serbia's reforms (on the path to EU). Collocation partners that preferably cooccur with Europa are highlighted 
in green; those that preferably cooccur with Serbia are highlighted in red. The occurrence Land - highlighted in white - behaves (within the discourse) equally to both words.

Sketch difference is a very promising analysis tool when it comes to discursive framing and imprinting effects. The example, that has just been mentioned, of course, does not claim representativeness; to this end, the corpus has to be aggrandized, such patterns have to be confirmed statistically and empirically.

\begin{tabular}{|lrrrr|}
\hline "europa/serbien" and/or ... & 10 & 125 & 0.15 & 0.43 \\
usa & 2 & 0 & 12.2 &.. \\
bildung & 1 & 0 & 11.5 &.. \\
asien & 1 & 0 & 11.4 &.. \\
afrika & 1 & 0 & 11.4 &.. \\
amerika & 1 & 0 & 11.2 &.. \\
russland & 2 & 0 & 10.7 &.. \\
sicherheit & 1 & 0 & 10.5 &.. \\
türkei & 1 & 0 & 9.9 &.. \\
china & 0 & 1 &.. & 7.7 \\
belgrad & 0 & 1 &.. & 7.8 \\
kosovo-albaner & 0 & 1 &.. & 8.0 \\
nachbarland & 0 & 1 &.. & 8.0 \\
kandidat & 0 & 1 &.. & 8.0 \\
vereinbarung & 0 & 1 &.. & 8.0 \\
republika & 0 & 1 &.. & 8.0 \\
mitte & 0 & 1 &.. & 8.0 \\
gebietstausch & 0 & 1 &.. & 8.0 \\
eu-entscheidung & 0 & 1 &.. & 8.0 \\
kolonialmacht & 0 & 1 &.. & 8.0 \\
bosnien-herzegowina & 0 & $\underline{2}$ &.. & 8.7 \\
eu & 0 & 3 &.. & 9.4 \\
mazedonien & 0 & 4 &.. & 9.4 \\
kroatien & 0 & 3 &.. & 9.5 \\
kosovo & 0 & $\underline{36}$ &.. & 12.2 \\
montenegro & 0 & 49 &.. & 12.9 \\
\hline
\end{tabular}

Figure 12. Sketch difference - Europa / Serbien, and/or

Figure 12 shows a sketch difference concerning collocation partners - cooccurring with the respective words (Europa/Serbien) - that are used in constructions with and/or. Europe occurs with USA, education, Asia, Africa, America, Russia, security and Turkey whereas Serbia, in the first instance, cooccurs with Montenegro, Kosovo, Croatia, Macedonia and, only then: EU, Bosnia-Herzegovina, colonial power ...

As to the sketch difference concerning the two lemmata Brüssel and Belgrad, the verbs used with Brüssel/Belgrad as subjects reveal interesting patterns, too. 


\begin{tabular}{|lrrrr|}
\hline verbs with "Brüssel/belgrad" as subject & 7 & 9 & 0.10 & 0.13 \\
drücken & 1 & 0 & 12.0 &.. \\
begrüßen & 1 & 0 & 11.8 & $\ldots$ \\
verlangen & 1 & 0 & 11.8 &.. \\
versprechen & 1 & 0 & 11.8 & $\ldots$ \\
entscheiden & 1 & 0 & 11.7 &.. \\
bemühen & 1 & 0 & 11.7 &.. \\
fordern & 1 & 0 & 10.8 & $\ldots$ \\
stellen & 0 & 1 &.. & 10.1 \\
machen & 0 & 1 &.. & 10.2 \\
sitzen & 0 & 1 &.. & 10.9 \\
lehnen & 0 & 1 &.. & 11.2 \\
setzen & 0 & 1 &.. & 11.2 \\
mischen & 0 & 1 &.. & 11.4 \\
schließen & 0 & 1 &.. & 11.5 \\
einschränken & 0 & 1 &.. & 11.7 \\
zurückschrecken & 0 & 1 &.. & 11.7 \\
\hline
\end{tabular}

Figure 13. Sketch difference - verbs with Brüssel / Belgrad as subject

Within the analyzed discourse - as shown in Figure 13 - Brussels rather pushes, welcomes, demands/requests, promises, decides, tries to make an effort, asks, ...whereas Belgrade shies away, restricts, closes, mixes, sets, leans, sits, makes, puts... Further word sketch differences will be analyzed as the corpus aggrandizes.

\section{Further research perspectives}

As already mentioned, this paper merely marks a starting point of a more wide-ranging study that tries to bring into focus Germanlanguage news discourse concerning the (possible) future enlargement of the European Union with regard to the Western Balkan countries (2025). Consequently, news coverage not only concerning Serbia, but also the other Western Balkan states will be considered.

This specific discourse will be further analyzed with regard to basic discursive figures (Diskursive Grundfiguren) which generate a dynamic semantic (discursive deep-) structure. These figures can be understood as (dynamic and more or less fragile) schemata that put elements of textual content in order. Semantic frames and social representations offer formats of representation for such structures. Indeed, the analyst has to carve out these figures interpretively, he cannot extract them all but objectively from the corpus; however, the analysis is based on linguistic investigations (constructions, forms, predications), not on mantic interpretation (of sense). 
The (pure) hermeneutic reading of this news discourse, of course, reveals a certain number of (prominent) discursive strands, too: land swap (Serbia/Kosovo) ; growing influence of China and Russia in the Western Balkan countries ; recognition of Kosovo (?) ; enlargement of the European Union 2025 compared to 2004 (eastern enlargement) and 2007 (Bulgaria, Rumania) ; European enlargement strategy: to export stability (rather than to import instability) ; Western Balkan countries as the European 'work bench' (economy); mood swings in Serbia / in the Balkans (towards the EU) ; instability on the European periphery ; ... The analysis, however, needs to go beyond hermeneutic-interpretive perspectives. The focus has to be laid now on the analysis of social representations and semantic frames since these formats act on verbalizations. Therefore, the study will zoom in on these social knowledge structures in order to find out how they influence the discursive universe. To this purpose, the Social Representation Theory - especially in coaction with Frame Semantics - is of high interest. Due to space restrictions, the interdisciplinary methodological approach could at this stage of the study - which merely showed possible approaches to the discursive surface structure - not yet manifest its potential. Further research will pick up these first (quantitative) empirical results and refine the analysis exploring discursive strands using semantic frames as analytical categories. The aim is to get insights into the rhizomatic structure of discursive figures, insights into particular utterance spaces in order to understand what is capable of being said, why something is capable of being said (or not said: l'hypothèse de la zone muette) and why a particular utterance is expressed in a particular context. 


\section{References}

Abric, Jean-Claude (ed.) (2003): Méthodes d'étude des representations sociales. Ramonville Saint-Agne: Éditions Érés.

Baker, Collin F. (2009): "La sémantique des cadres et le projet FrameNet: une approche différente de la notion de "valence"“. In: Languages, 176/4 2009. 32-49.

Becker, Jens / Achim Engelberg (eds.) (2008): Serbien nach den Kriegen. Frankfurt am Main: Suhrkamp.

Behrens, Heike / Pfänder, Stefan (eds.) (2016): Experience Counts: Frequency Effects in Language. Berlin/Boston: De Gruyter.

Busse, Dietrich / Teubert, Wolfgang (2013): "Ist Diskurs ein sprachwissenschaftliches Objekt? Zur Methodenfrage der historischen Semantik“. In: Busse, Dietrich / Teubert, Wolfgang (eds.): Linguistische Diskursanalyse: neue Perspektiven. Wiesbaden: Springer VS. 13-30.

Chomsky, Noam (1980): Rules and Representations. New York: Columbia Press. Dahm, Johannes (2018): Diskurslinguistische Perspektiven auf Soziale Repräsentationen. Berlin: Peter Lang.

Džalto, Davor (ed.) (2018): Yugoslavia. Peace, War and Dissolution. Noam Chomsky. Oakland: PM Press.

Evert, Stefan (2005): The Statistics of Word Cooccurrences: Word Pairs and Collocations. Dissertation: 'Institut für maschinelle Sprachverarbeitung', Universität Stuttgart.

Fillmore, Charles J. (1982): "Frame Semantics". In: The linguistic Society of Korea (ed.): Linguistics in the morning calm. Selected Papers from SICOL-1981. Seoul: Hanshin Publishing Company. 111-137.

Foucault, Michel (1973): Archäologie des Wissens. Frankfurt am Main: Suhrkamp.

Fraas, Claudia (2005): "Schlüssel-Konzepte als Zugang zum kollektiven Gedächtnis. Ein diskurs- und frameanalytisch basierter Ansatz". In: Deutsche Sprache, 3/2005. 242-257.

Giora, Rachel (2003): On our Mind. Salience, Context and Figurative Language. Oxford: Oxford University Press.

Handke, Peter (1996): Eine winterliche Reise zu den Flüssen Donau, Save, Morawa und Drina oder Gerechtigkeit für Serbien. Frankfurt am Main.: Suhrkamp.

Jodelet, Denise (ed.) (2003): Les représentations sociales. Paris: PUF.

Kapranov, Oleksandr (2016): "The Framing of Serbia's EU Accession by the British Foreign Office on Twitter". In: Tekst I Dyskurs - Text und Diskurs, 9/2016. 71- 84. 
Kilgarriff, Adam / Baisa Vít / Bušta, Jan / Jakubícek, Miloš / Kovář, Vojtěch / Michelfeit, Jan / Rychlý, Pavel / Suchomel, Vit (2014): "The Sketch Engine: ten years on“. In: Lexicography, 1/1 2014. 7-36. Online: https:// link.springer.com/ article/\%2010.1007/s40607-014-0009-9.

Langacker, Ronald W. (1988): "A usage-based model". In: Rudzka-Ostyn, Brygida (ed.): Topics in Cognitive Linguistics. Amsterdam: Benjamins. 49-90.

Lasch, Alexander (2016): Nonagentive Konstruktionen des Deutschen. Berlin/ Boston: De Gruyter.

Lecheler, Sophie / De Vreese, Claes H. (2010): "Framing Serbia: the effects of news framing on public support for EU enlargement". In: European Political Science Review, Volume 2, Issue 1 2010. 73-93.

Moscovici, Serge (1961): La Psychanalyse, son image et son public. Paris: PUF. Rychlý, Pavel (2008): "A lexicographer-friendly association score". In: Conference proceedings. Sojka, Petr / Horák Aleą (eds.): Proceedings of Recent Advances in Slavonic Natural Language Processing - RASLAN. Brno, 5.-7.12.2008. Brno: Masaryk University. 6-9. Online: http://www. fi.muni.cz/usr/sojka/download/raslan2008/13. pdf.

Todorova, Maria (1997): Imagining the Balkans. Oxford, New York: Oxford University Press.

Williams, Geoffrey (1998): “Collocational Networks: Interlocking Patterns of Lexis in a Corpus of Plant Biology Research Articles". In: International Journal of Corpus Linguistics, 3/1 1998.151-171.

Ziem, Alexander (2008): Frames und sprachliches Wissen. Kognitive Aspekte der semantischen Kompetenz. Berlin: De Gruyter. 


\section{Johannes Dahm}

\section{"SERBIA AND THE EU": DISCURSIVE FRAMING AND IMPRINTING EFFECTS ON RECURRENT SPEECH PATTERNS USED IN THE GERMAN-LANGUAGE PRESS}

Summary: This communication marks the starting point of a more wide-ranging study that covers German-language news discourse concerning the possible future enlargement of the European Union with regard to the Western Balkan countries (2025). Based on a(n) (interdisciplinary) theoretical framework, this research study interrelates concepts partially developed in the environment of cognitive sciences (i.a. cognitive psychology and cognitive linguistics: scripts, scenes, schemes ; prototypes / semantic frames ; usage-based models of language) with concepts and perspectives that are more and more considered in the environment of sociolinguistic research (i.a. discourse analysis and corpus linguistics: the discursive influence on socio-cognitive patterns / frequency effects, salience...). In order to approach the topic, this paper brings into focus a corpus linguistic perspective. It analyses the surface of the current German-language press discourse concerning the accession of Serbia to the European Union against the background of selected press articles $(2018,2017)$ related to this particular issue. Discursive framing and imprinting effects on recurrent speech patterns will be uncovered using Sketch Engine - a text analysis software.

Key words: Discourse studies, Corpus linguistics, German-language press, Serbia, European Union, Framing 